\title{
Synthesis, Characterization and Study of Antimicrobial Activities of Mannich Bases Incorporating 1,2,4-Triazole Nucleus
}

\author{
Rhambus Rawat, Prem Shankar Deo, Bhushan Shakya* \\ Department of Chemistry, Amrit Campus, Tribhuvan University, Kathmandu, Nepal \\ *E-mail: bhusansakya@gmail.com
}

(Received:2 March 2021, Received in revised form: 20 April, Accepted: 27 June 2021, Available Online)

\section{Highlights}

- $\quad$ Some new Mannich bases incorporating 1,2,4-triazole nucleus were synthesized.

- Mannich bases were characterized by spectral techniques \& antimicrobial activities studied.

- Mannich bases were much more effective than Schiff base against microbial strains.

- Antimicrobial activities influenced by the bulkiness of substituent $\&$ electron density at $N 1$ of triazole nucleus.

\begin{abstract}
Heterocyclic compounds containing triazole moiety have great importance in the field of medicine, pharmaceuticals, biochemistry, biology, therapeutics, environmental science, and industry. Triazoles and their derivatives have been extensively used in the development of new drugs. Biological activities of Schiff bases are highly investigated, but Mannich bases are on the verge of their development, and they are being synthesized in large number nowadays. In this work, Mannich bases are synthesized by incorporation 1,2,4-triazole moiety through Schiff base using different amines. Mannich bases are found to exhibit highly effective antibacterial and antifungal activities. The formation of synthesized compounds - 1,2,4-triazole-5-thione, Schiff base (4) and Mannich bases (5a and 5b) - are confirmed and characterized by spectroscopic techniques like UV, FTIR ${ }^{1} H$-NMR and ${ }^{13} C-N M R$. The activity of the synthesized compounds was tested against bacterial and fungal strain.
\end{abstract}

Keywords: 1,2,4-triazole, Schiff base, Mannich base, Antibacterial, Antifungal

\section{Introduction}

The increasing drug resistant capacity of microbes demands the development of new drugs with multisite mechanism to deprive the pathogenicity of microbes. Heterocyclic chemistry has been chosen as the most useful branch to design the required composition [1-3]. Heterocyclic chemistry has its own pattern in the synthesis of drugs [4], pesticides [5] and detergents [6] by using reagents and synthetic methods. It is widely used in the fields of pharmacology, medicinal chemistry, biochemistry [7], polymers [8, 9], dyes [10, 11] and material science [12]. Nowadays, the nucleus of triazole is used as the main structure for synthesizing much known marketed drugs. On comparison to other nuclei, it is found that triazoles are less susceptible to metabolic degradation and have excellent target specificity with a wide range of activities [13, 14].

1,2,4-triazole derivatives possess biological activities including antibacterial [15, 16], antifungal [17-19], antitubercular [20], antiviral [21], antimalarial [22], anti-inflammatory [23], anticonvulsant [24], anticancer [25, 26], analgesic [27], antioxidant [28], antimigraine [29] and potassium channel activators [30]. Along with these, it has agricultural, industrial, environmental activities. Some of the known drugs having 1,2,4-triazole nucleus are Triazolam [31], Alprazolam [32], Fluconazole, Voriconazole [33, 34], Furacylin [35], Etizolam [36], etc.

${ }^{*}$ Corresponding author 
The incorporation of a heterocyclic ring is one of the most investigated reactions in the synthesis of new drugs. One of the most important organic reaction which uses heterocyclic compounds is Mannich reaction. It involves aminoalkylation of an acidic proton next to a carbonyl functional group with formaldehyde and ammonia or any primary amine or secondary amine to yield $\beta$-aminoketone also called as Mannich base. Mannich bases can be easily converted to numerous other compounds by changing the functional group. Mannich bases have pharmacological activities like analgesic, anti-inflammatory, anaesthetic and antimicrobial activities and are used as intermediates in drug synthesis as well [37, 38].

Mannich bases were synthesized through Mannich reaction using diphenylamine and piperazine with a 1,2,4-triazole moiety having Schiff base.

\section{Materials and Methods}

\section{Starting Materials}

The precursors for the synthesis of triazole viz. Hydrazine monohydrate and formaldehyde (Qualigens), carbon disulphide and diphenylamine (Merck), ethanol (Changshu Honsgsheng Fine Chemical), anisaldehyde and methyl salicylate (Fischer scientific), piperazine (Loba Chemie) were purchased from commercial sources and were used as received.

\section{Physical Measurements}

Optics technology melting apparatus was used to determine the melting points of synthesized compounds. TLC of synthesized compounds was done by using silica gel coated plates, using $n$-hexane: ethyl acetate solvent system and the spots were visualized by using iodine vapours in an iodine chamber. The UV-visible spectrophotometer of Labtronics (Model LT-2802) was used to record the visible absorption spectra in DMSO of the synthesized compounds in the region 1100-200 nm. FT-IR spectra were measured in the range of (4000-400) $\mathrm{cm}^{-1}$. The measurement was done in IR prestige-21, Shimadzu, Japan. ${ }^{1} \mathrm{H}-\mathrm{NMR}$ and ${ }^{13} \mathrm{C}$-NMR spectroscopy of synthesized compounds were recorded on Bruker AV III 500MHz NMR spectrometer using DMSO as the solvent, and chemical shifts are expressed in $\delta \mathrm{ppm}$.

\section{Synthesis and Analysis}

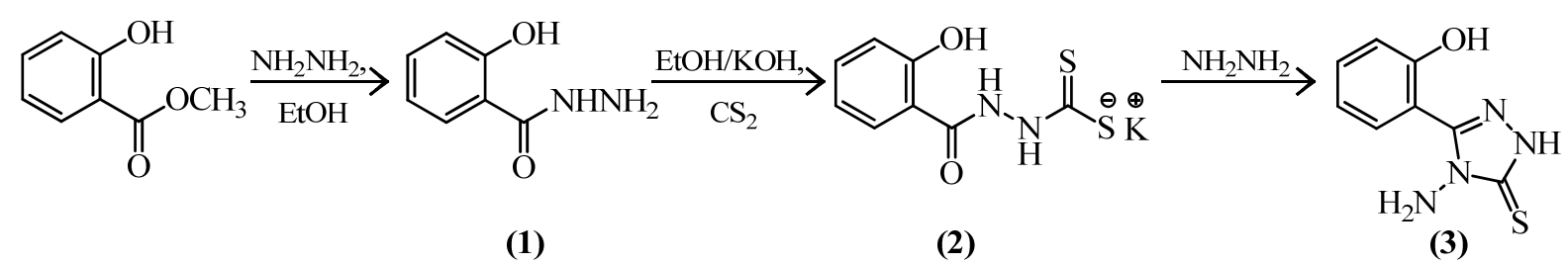

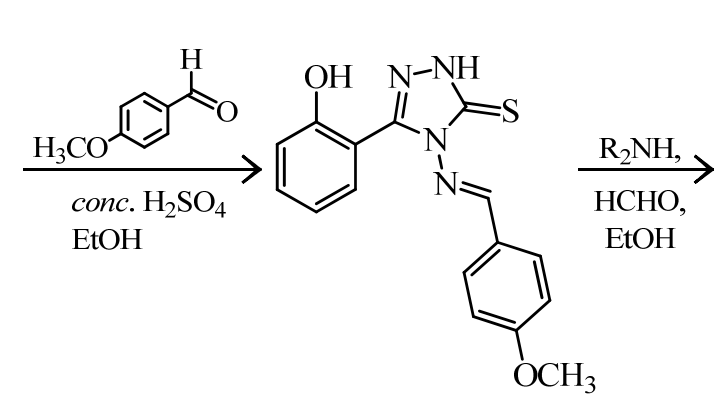

(4)<smiles>[R12]Cn1nc(-c2ccccc2O)n(/N=C/c2ccc(OC)cc2)c1=S</smiles>

(5)

Scheme 1: Synthetic route for Mannich base of 1,2,4-triazole

\section{Synthesis of 2-hydroxybenzohydrazide (1)}

A mixture of methyl salicylate $(0.06 \mathrm{~mol})$ and $99 \%$ hydrazine monohydrate $(0.09 \mathrm{~mol})$ was refluxed for 6 hours. Total volume was reduced to half by evaporating the excess solvent and was cooled. The solid was separated by suction filtration, washed with cold ethanol, recrystallized from absolute ethanol and dried in an air oven at 50-60 ${ }^{\circ} \mathrm{C}$. Yield: $80 \%$ (7.325 g, $\left.0.048 \mathrm{~mol}\right)$; white shining crystalline solid; m.p.:147-150 ${ }^{\circ} \mathrm{C} ; \mathrm{R}_{f}: 0.66$ ( $n$-hexane: ethyl acetate, 8:2). 
Synthesis of Potassium-2-(2-hydroxybenzoyl)hydrazinecarbodithioate (2)

2-hydroxybenzohydrazide (1) $(0.03 \mathrm{~mol})$ was added to $20 \mathrm{~mL}$ ethanolic solution of potassium hydroxide $(0.03 \mathrm{~mol})$ at ice-cold condition. Carbon disulphide $(0.03 \mathrm{~mol})$ was added dropwise, and the reaction mixture was stirred for $21 \mathrm{~h}$ at room temperature. The mixture was diluted with $20 \mathrm{~mL}$ of anhydrous diethyl ether, the crude solid was washed twice with anhydrous diethyl ether and dried in a desiccator. Yield: $64 \%$ (5.103 g, $0.0191 \mathrm{~mol})$; white crystalline solid; m.p.: $240{ }^{\circ} \mathrm{C} ; \mathrm{R}_{f} ; 0.58$ ( $n$-hexane : ethyl acetate, 8:2).

\section{Synthesis of 4-amino-3-(2-hydroxyphenyl)-1H-1,2,4-triazole-5-thione (3)}

A suspension containing potassium-2-(2-hydroxybenzoyl) hydrazinecarbodithioate (2) $(0.015 \mathrm{~mol})$ in $5 \mathrm{~mL}$ distilled water and $1.48 \mathrm{~mL}$ of hydrazine monohydrate was refluxed till hydrogen sulphide gas was ceased. The reaction mixture was cooled, diluted with $100 \mathrm{~mL}$ of water containing some crushed ice and acidified with conc. hydrochloric acid. The solid was filtered, washed and recrystallized with absolute ethanol. Yield: $81 \%(2.541 \mathrm{~g}, 0.0122 \mathrm{~mol})$; white crystalline solid; m.p.: $168{ }^{\circ} \mathrm{C} ; \mathrm{R}_{f}$ : 0.35 ( $n$-hexane : ethyl acetate, 8:2). UV-Visible spectrum $\left(\lambda_{\max }\right) \mathrm{nm}=302,309,331,353$. IR spectrum $\mathrm{cm}^{-1}=3287,3186,3063$,

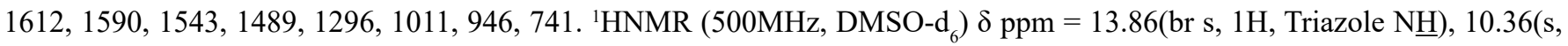
$1 \mathrm{H}, \mathrm{OH}), 7.31-7.51(\mathrm{~m}, 2 \mathrm{H}, \mathrm{Ar}-\mathrm{H}), 7.00(\mathrm{~d}, J=8.20 \mathrm{~Hz}, 1 \mathrm{H}, \mathrm{Ar}-\mathrm{H}), 6.93(\mathrm{t}, J=7.57 \mathrm{~Hz}, 1 \mathrm{H}, \mathrm{Ar}-\mathrm{H}), 5.62\left(\mathrm{br} \mathrm{s}, 2 \mathrm{H}, \mathrm{NH}_{2}\right) .{ }^{13} \mathrm{C}-\mathrm{NMR}$ $(100 \mathrm{MHz}$, DMSO-d 6 ) $\delta \mathrm{ppm}=165.54($ Triazole-C5), 156.53(Ar-C), 149(Triazole-C3), 132.60(Ar-C), 131.32(Ar-C), 119.53(ArC), 116.67(Ar-C), 113.52 (Ar-C).

\section{Synthesis of Schiff base 3-(2-hydroxyphenyl)-4-(4-methoxybenzylideneamino)-1H-1,2,4-triazole-5-thione (4)}

Anisaldehyde ( $0.01 \mathrm{~mol})$ and conc. sulphuric acid (5 drops) were added to a hot ethanolic solution of triazole thione (3) (0.01 $\mathrm{mol})$, and refluxed for 5 hours. The mixture was cooled, filtered under suction, washed with cold ethanol and recrystallized with hot ethanol. Yield: $62 \%(2.051 \mathrm{~g}, 0.006 \mathrm{~mol})$; yellowish white crystalline solid; m.p.: $180{ }^{\circ} \mathrm{C} ; \mathrm{R}_{f}: 0.74$ ( $n$-hexane : ethyl acetate, 8:2). UV-Visible spectrum $\left(\lambda_{\max }\right) \mathrm{nm}=302,309,336,379$. IR spectrum $\mathrm{cm}^{-1}=3286(\mathrm{~m}), 3248(\mathrm{~m}), 3061(\mathrm{~m}), 2916(\mathrm{~m}), 1597(\mathrm{~m})$, 1551(m), 1504(m), 1481(s), 1304(m), 1234(s) 1026(m), 825(m), 748(m). ${ }^{1} \mathrm{HNMR}\left(500 \mathrm{MHz}\right.$, DMSO-d $\left.{ }_{6}\right) \delta, \mathrm{ppm}=14.04(\mathrm{br} \mathrm{s}$, $1 \mathrm{H}$, Triazole $\underline{\mathrm{H}}$ ), 10.90 (br s, $1 \mathrm{H}, \mathrm{O} \underline{\mathrm{H}}$ ), 9.37(br s $1 \mathrm{H}, \mathrm{N}=\mathrm{C} \underline{\mathrm{H}}$ ), 7.94(d, $J=8.20 \mathrm{~Hz}, 1 \mathrm{H}, \mathrm{Ar}-\mathrm{H}), 7.66-7.78$ (dd, $J=8.20,7.57 \mathrm{~Hz}$, $1 \mathrm{H}, \mathrm{Ar}-\mathrm{H}), 7.30-7.51(\mathrm{~m}, 2 \mathrm{H}, \mathrm{Ar}-\mathrm{H}), 7.04(\mathrm{~m}, 1 \mathrm{H}, \mathrm{Ar}-\mathrm{H}), 6.93-7.02(\mathrm{~m}, 2 \mathrm{H}, \mathrm{Ar}-\mathrm{H}), 6.91(\mathrm{~d}, J=7.57 \mathrm{~Hz}, 1 \mathrm{H}, \mathrm{Ar}-\mathrm{H}), 3.82(\mathrm{~s}, 3 \mathrm{H}$, $\left.\mathrm{OC}_{3}\right) .{ }^{13} \mathrm{C}-\mathrm{NMR} \delta, \mathrm{ppm}=166.29(\mathrm{Ar}-\mathrm{C}), 163.30$ (Triazole-C5), 159.00(Triazole-C3), 156.61(Ar-C), 148.67(Ar-C), 134.55(ArC), 131.57(Ar-C), 131.05(Ar-C), 129.30(Ar-C), 119.71(Ar-C), 117.73(Ar-C), 115.41(Ar-C), 115.06(Ar-C), 56.00( $\left.\mathrm{O}_{2} \mathrm{H}_{3}\right)$.

\section{Synthesis of Mannich bases}

$40 \%$ formaldehyde $(0.2 \mathrm{~mL})$ and desired amine $(0.003 \mathrm{~mol})$ were added to a hot ethanolic solution of Schiff base (4) $(0.003$ mol) and refluxed for 3 hours. An excess amount of distilled water was added and left overnight. The solid was filtered under suction, washed with cold ethanol and recrystallized from absolute ethanol.

2-(diphenylamino)methyl-3-(2-hydroxyphenyl)-4-(4-methoxybenzylideneamino)-1H-1,2,4-triazole-5-thione (5a):Yield: $60 \%$ (0.916 g, $0.0018 \mathrm{~mol}$ ); yellowish white crystalline solid; m.p.:122 ${ }^{\circ} \mathrm{C} ; \mathrm{R}_{\mathrm{f}}: 0.72$ ( $n$-hexane : ethyl acetate, 8:2). UV-Visible spectrum $\left(\lambda_{\max }\right) \mathrm{nm}=302,309,338,378$. IR spectrum $\mathrm{cm}^{-1}=3201,3055,2839,1597,1551,1481,1444,1303,1234,1026,833$, 748. ${ }^{1} \mathrm{HNMR}\left(500 \mathrm{MHz}, \mathrm{DMSO}-\mathrm{d}_{6}\right) \delta \mathrm{ppm}=10.09(\mathrm{~s}, 1 \mathrm{H}, \mathrm{OH}), 9.27(\mathrm{~s}, 1 \mathrm{H}, \mathrm{N}=\mathrm{C} \underline{\mathrm{H}}), 7.94(\mathrm{~d}, J=7.57 \mathrm{~Hz}, 1 \mathrm{H}, \mathrm{Ar}-\mathrm{H}), 7.87(\mathrm{dd}$, $J=8.20 \times(2) \mathrm{Hz}, 1 \mathrm{H}, \mathrm{Ar}-\mathrm{H}), 7.75$ (d, $J=8.83 \mathrm{~Hz}, 2 \mathrm{H}, \mathrm{Ar}-\mathrm{H}), 7.46$ (m, 1H, Ar-H), 7.28-7.39 (m, 4H, Ar-H), 7.13 (d, $J=8.83$ $\mathrm{Hz}, 2 \mathrm{H}, \mathrm{Ar}-\mathrm{H}), 6.94-7.08$ (m, 2H, Ar-H), 6.85-6.93 (d, J=8.20 Hz, 1H, Ar-H), 6.16 (br s, 2H, N-C $\left.\underline{H}_{2}-\mathrm{N}\right), 3.82\left(\mathrm{~s}, 3 \mathrm{H}, \mathrm{OC} \underline{H}_{3}\right)$. ${ }^{13} \mathrm{C}-\mathrm{NMR}\left(100 \mathrm{MHz}, \mathrm{DMSO}-\mathrm{d}_{6}\right) \delta \mathrm{ppm}=191.80$ (Triazole-C5), 166.29(Ar-C), 159.01(Ar-C), 156.61(N=ㄴH), 147.99(Ar-C), 146.66(Triazole-C3), 134.57(Ar-C), 131.51(Ar-C), 129.59(Ar-C), 129.28(Ar-C), 124.88(Ar-C), 123.01(Ar-C), 121.92(Ar-C), 120.11(Ar-C), 117.74(Ar-C), 115.10(Ar-C), 115.00(Ar-C), 64.93( $\left.\mathrm{N}_{-} \underline{\mathrm{CH}}_{2}-\mathrm{N}\right), 56.03\left(\mathrm{OCH}_{3}\right)$.

3-(2-hydroxyphenyl)-4-(4-methoxybenzylideneamino)-2-(piperazin-1-ylmethyl)-1H-1,2,4-triazole-5-thione (5b): Yield: 65 $\%(0.829 \mathrm{~g}, 0.0020 \mathrm{~mol})$; Greyish white crystalline solid; m.p.: $132{ }^{\circ} \mathrm{C} ; \mathrm{R}_{\mathrm{f}}: 0.89$ ( $n$-hexane : ethyl acetate, 8:2). UV-Visible spectrum $\left(\lambda_{\max }\right) \mathrm{nm}=303,309,339,379$. IR spectrum $\mathrm{cm}^{-1}=3248,3148,3070,2831,1628,1597,1489,1450,1304,1242$, 1026, 825, 741. ${ }^{1} \mathrm{HNMR}\left(500 \mathrm{MHz}, \mathrm{DMSO}-\mathrm{d}_{6}\right) \delta \mathrm{ppm}=10.11(\mathrm{br} \mathrm{s}, 1 \mathrm{H}, \mathrm{OH}), 9.30(\mathrm{~s}, 1 \mathrm{H}, \mathrm{N}=\mathrm{C} \underline{\mathrm{H}}), 7.88(\mathrm{~d}, J=8.83 \mathrm{~Hz}, 1 \mathrm{H}, \mathrm{Ar}-\mathrm{H})$, $7.76(\mathrm{~d}, J=8.83 \mathrm{~Hz}, 1 \mathrm{H}, \mathrm{Ar}-\mathrm{H}), 7.71(\mathrm{~d}, J=8.20 \mathrm{~Hz}, 2 \mathrm{H}, \mathrm{Ar}-\mathrm{H}), 7.41-7.48(\mathrm{~m}, 1 \mathrm{H}, \mathrm{Ar}-\mathrm{H}), 7.14(\mathrm{~d}, J=8.2 \mathrm{~Hz}, 2 \mathrm{H}, \mathrm{Ar}-\mathrm{H}), 6.90-$ 7.01(d, $J=8.20 \mathrm{~Hz}, 1 \mathrm{H}, \mathrm{Ar}-\mathrm{H}), 5.14\left(\mathrm{br} \mathrm{s}, 2 \mathrm{H}, \mathrm{N}-\mathrm{C}_{2}-\mathrm{N}\right), 3.87$ (br s, 4H, Piperazine- $\left.\mathrm{C}_{2}\right), 3.79-3.85\left(\mathrm{~m}, 7 \mathrm{H}\right.$, Piperazine-C $\underline{\mathrm{H}}_{2} \&$

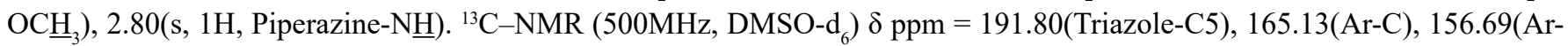


C), 156.62( $\mathrm{N}=\underline{\mathrm{CH}}$ ), 149.13(Triazole-C3), 132.29(Ar-C), 129.37(Ar-C), 128.88(Ar-C), 119.33(Ar-C), 117.78(Ar-C), 115.08(ArC), 115.00(Ar-C), 69.40( $\left.\mathrm{N}_{-} \underline{\mathrm{H}}_{2}-\mathrm{N}\right), 56.16\left(\mathrm{OCH}_{3}\right), 56.02$ (Piperazine-C), 55.80(Piperazine-C),

\section{Antimicrobial Screening}

The antimicrobial activity of the newly synthesized Mannich bases was screened against gram-positive bacterial strain Bacillus subtilis, Enterococcus faecalis, Staphylococcus aureus; gram-negative bacterial strain- Escherichia coli, Klebsiella pneumoniae, Proteus vulgaris, Pseudomonas aeruginosa, Salmonella typhii, Shigella dysenteriae; and fungal strain- Candida albicans, Saccharomyces cerevisiae. Required numbers of colonies of freshly cultured (within 18-24 hours) test organisms were inoculated aseptically to a tube containing $5 \mathrm{~mL}$ of sterilized nutrient broth and homogenized by vortexing. The synthesized compounds were screened for antimicrobial activity using agar well diffusion methods as described by Perez [39]. Swabbing was done by using the appropriate medium Muller-Hinton Agar (MHA) for bacteria and Muller-Hinton Agar with Glucose and Methylene Blue (MHA, GMB) for fungi. The inoculated plates were then incubated in an inverted position at a suitable temperature $\left(35 \pm 2{ }^{\circ} \mathrm{C}\right.$ for bacteria and $25 \pm 2{ }^{\circ} \mathrm{C}$ for fungi), and zone of inhibition (ZOI) were examined around the well, which was suggested by a clear area with no growth of organisms. Activity of compounds were compared with Chloramphenicol as standard (Positive Control) for bacteria while Clotrimazole was used as standard (Positive Control) to analyze fungi.

\section{Results and Discussion}

\section{Chemistry}

Mannich bases $\mathbf{5 a}$ and $\mathbf{5 b}$ were synthesized from Schiff's base having 1,2,4-triazole-5-thione moiety as shown in scheme 1. Hydrazine hydrate and ethanol were mixed to the methyl salicylate and refluxed to obtain acid hydrazide (1), which on reaction with alc. potassium hydroxide and carbon disulphide gave dithiocarbazinate (2). Ring closure of compound (2) in the presence of excess hydrazine hydrate in ethanol results 4-amino-3-(2-hydroxyphenyl)-1H-1,2,4-triazole-5-thione (3). 3-(2-hydroxyphenyl)4-(4-methoxybenzylideneamino)-1H-1,2,4-triazole-5-thione (4) is formed by the condensation of 1,2,4-triazole (3) with anisaldehyde on refluxing ethanolic solution in the presence of a catalytic amount of conc. sulphuric acid. Finally, Mannich base (5a) was obtained by refluxing formaldehyde, ethanolic solution of Schiff base (4) and diphenylamine, whereas (5b) was obtained by refluxing formaldehyde, ethanolic solution of Schiff base (4) and piperazine.

\section{Spectroscopic Studies}

The spectral techniquesUV, FT-IR, ${ }^{1} \mathrm{HNMR},{ }^{13} \mathrm{CNMR}$ were used to confirm the structure of synthesized compounds (3), (4), (5a) and (5b).

\section{UV-Visible analysis}

In UV-spectra triazole thione (3) exhibited four bands while Schiff base (4) and Mannich bases (5a \&5b) exhibited five bands. The first two bands observed at $302 \mathrm{~nm}$ and $309 \mathrm{~nm}$ are attributed to aromatic $\mathrm{C}=\mathrm{C}$ and azomethine $\mathrm{C}=\mathrm{N}\left(\pi \rightarrow \pi^{*}\right)$ of triazole ring, respectively. The third band at $331 \mathrm{~nm}$ (in compound3), $336 \mathrm{~nm}$ (in Schiff base 4), $338 \mathrm{~nm}$ (in Mannich base 5a) and $339 \mathrm{~nm}$ (in Mannich base $\mathbf{5 b}$ ) is due to non-bonding electron pair of triazole nitrogen atoms and sulphur atom of thione group $\mathrm{C}=\mathrm{S}\left(\mathrm{n} \rightarrow \pi^{*}\right)$. The fourth band at $353 \mathrm{~nm}$ (in compound 3) and $355 \mathrm{~nm}$ (in Schiff base and Mannich bases) is due to $\left(\mathrm{n} \rightarrow \pi^{*}\right)$ transition of the $o$-hydroxy group. The fifth band at $378(\mathbf{5 a})$ and $379 \mathrm{~nm}(\mathbf{4} \& \mathbf{5 b})$, indicates azomethine group $\mathrm{C}=\mathrm{N}[40]$.

\section{FT-IR analysis}

The formation of triazole is confirmed by the presence of a medium band at $1296 \mathrm{~cm}^{-1}$ and a strong band at $946 \mathrm{~cm}^{-1}$ corresponding to thioamide II (N-C=S) and thioamide IV $(\mathrm{C}=\mathrm{S})$. Furthermore, no absorption bands were detected about 1651$1707 \mathrm{~cm}^{-1}$, indicating the absence of the $\mathrm{C}=\mathrm{O}$ group of the compound, which is the evidence for the conversion of dithiocarbazinate into triazoles [41]. The lack of band at $1700 \mathrm{~cm}^{-1}$ clearly indicates the amino condensation and hence the formation of Schiff bases [42]. This is further supported by the absence of medium intensity bands in the region of $3500-3200 \mathrm{~cm}^{-1}$ attributable to $\mathrm{NH}_{2}$ stretching [43]. Moreover, the absence of an absorption band in the region of 2300-2600 $\mathrm{cm}^{-1}$ region cited for the $-\mathrm{SH}$ group clearly states that, in the solid-state, the compound exists predominantly in the thionic form [44, 45]. The medium absorption band found at the region of $1303 \mathrm{~cm}^{-1}$ refers to the $\mathrm{N}-\mathrm{C}=\mathrm{S}$ (thioamide II) group in (5a), whereas the same group is found at the 
region of $1304 \mathrm{~cm}^{-1}$ in (5b). For the thioamide IV group, the absorption bands are observed at $833 \mathrm{~cm}^{-1}$ and $825 \mathrm{~cm}^{-1}$ respectively for $(\mathbf{5 a})$ and $(\mathbf{5 b})$. The formation of Mannich bases (5a) and (5b) is supported by the presence of medium absorption band at 1303 $\mathrm{cm}^{-1}$ and weak absorption band at $1304 \mathrm{~cm}^{-1}$ respectively due to the $\mathrm{N}-\mathrm{C}=\mathrm{S}$ group. Besides, the absence of absorption band at 2250 $\mathrm{cm}^{-1}$ due to S-H structure supports the formation of $N$ - Mannich bases but not $S$ - Mannich bases [42].

\section{${ }^{1}$ HNMR}

In the ${ }^{1} \mathrm{HNMR}$ spectrum of compound (3), the broad singlet at $13.86 \mathrm{ppm}$ is attributed to the $-\mathrm{NH}$ group, which suggests the formation of thione based triazole [46]. This event is also supported by the absence of IR absorption band at $2600 \mathrm{~cm}^{-1}$ due to the thiol group. The Schiff base (4) contains the singlet at $14.04 \mathrm{ppm}$ due to the presence of the NH proton. The singlet at $10.06 \mathrm{ppm}$ is attributed to the hydrogen of the $\mathrm{OH}$ group. Moreover, the ${ }^{1} \mathrm{H}-\mathrm{NMR}$ spectrum of Schiff base showed a singlet at 9.37 due to the presence of $-\mathrm{N}=\mathrm{CH}$ group. The confirmation of formation of the Schiff base is done by the absence of signals approximately at $5.76 \mathrm{ppm}\left(\mathrm{NH}_{2}\right)$ in the molecule.In compound $(\mathbf{5 a})$ and $(\mathbf{5 b})$, the peak obtained due to the $-\mathrm{NH}$ proton is absent. The signal due piperazine ring proton $\left(\mathrm{CH}_{2}, \mathbf{5 b}\right)$ was found to be quartets at $3.87 \mathrm{ppm}$ [47] and while that due to the $-\mathrm{NH}$ of piperazine was found to be broad singlet at $2.80 \mathrm{ppm}$. The singlets at $6.16 \mathrm{ppm}$ and $5.14 \mathrm{ppm}$ in the spectra of (5a) and (5b) respectively due to the $\mathrm{N}_{-} \mathrm{CH}_{2}-\mathrm{N}$ group confirms the formation of Mannich bases from the Schiff base. The absence of a peak at 11.5 ppm clearly suggests the absence of thiol group in the structure, and hence the formation of thione based Mannich base [42].

\section{${ }^{13}$ CNMR}

The peak corresponding to resonance of triazole $\mathrm{C} 5$, i.e. $\mathrm{C}=\mathrm{S}$ is observed at $165.54,163.30,191.80$ and $191.80 \mathrm{ppm}$, respectively in the compounds (3), (4), (5a) \& (5b)[47]. The signal of $\mathrm{C}=\mathrm{N}$ is observed at 149.62, 148.67, 146.66 and 149.13 ppm for compounds (3), (4), (5a) \&(5b), respectively. The signal at $156.61 \mathrm{ppm}$ attributable to the azomethine carbon confirms the formation of the Schiff base [48]. Similarly, the peaks observed at 156.61 and $156.64 \mathrm{ppm}$ were associated with the $-\mathrm{N}=\mathrm{CH}$ group in compound (5a) $\&(\mathbf{5 b})$, respectively. In the spectra (5b), the piperazine carbons exhibited resonance in the region of 55.08 and $56.02 \mathrm{ppm}$. The methoxy carbon in the compound (4), (5a)\& (5b) are found to give peaks at 56.00, 56.03, and $56.16 \mathrm{ppm}$, respectively. The formation of Mannich bases (5a)\& (5b) was confirmed by a peak at $64.93 \mathrm{ppm}$ and $69.40 \mathrm{ppm}$, respectively.

\section{Antimicrobial Screening}

The antibacterial activity of the synthesized compounds exhibited moderate activity against the tested bacterial strains using Chloramphenicolas standard (positive control). Mannich bases (5a) and (5b) are more active than the Schiff base (4) against the tested bacterial strain. Compound (5b) showed more potent activity than (5a) against many bacterial strains. Both bases (5a) and (5b) have shown high activity against $P$. vulgarisin comparison to other tested bacterial strain, whereas compound (4) is ineffective with P. vulgaris. B. subtilis shows no response towards both the Mannich bases but the Schiff base (4) has some effect on it.

Table 1. Inhibition zones showing antimicrobial activities of Mannich bases and reference antibiotic

\begin{tabular}{|l|c|c|c|c|c|}
\hline \multirow{2}{*}{ Strain } & \multicolumn{5}{|c|}{ Diameter of zone of inhibition (mm) } \\
\cline { 2 - 6 } & 4 & $5 \mathrm{a}$ & $5 \mathrm{~b}$ & Chloramphenicol (PC) $^{\text {Clotrimazole (PC) }}$ \\
\hline Bacillus subtilis $^{a}$ & 7.1 & 0.0 & 0.0 & 26.58 & NT \\
Enterococcus faecalis $^{a}$ & 0.0 & 8.49 & 8.34 & 20.86 & NT \\
Escherichia coli $^{b}$ & 6.8 & 7.48 & 8.95 & 22.75 & NT \\
Klebsiella pneumonias $^{b}$ & 8.86 & 7.4 & 10.22 & 12.28 & NT \\
Proteus vulgaris $^{b}$ & 0.0 & 10.45 & 11.94 & 0.0 & NT \\
Pseudomonas aeruginosa $^{b}$ & 7.6 & 7.58 & 9.53 & 12.28 & NT \\
Salmonella typhii $^{b}$ & 7.66 & 7.30 & 8.93 & 27.44 & NT \\
Shigella dysenteriae $^{b}$ & 7.12 & 0.0 & 8.52 & 28.99 & NT \\
Staphylococcus aureus $^{a}$ & 7.78 & 9.82 & 12.30 & 28.40 & NT \\
Candida albicans $^{f}$ & 9.0 & 15.55 & 16.45 & NT & 32.33 \\
Saccharomyces cerevisiae $^{f}$ & 10.02 & 11.84 & 14.32 & NT & 24.33 \\
\hline
\end{tabular}

${ }^{a}$ Gram-positive bacteria; ${ }^{b}$ Gram-negative bacteria; ${ }^{f}$ Fungal strain; NT $=$ Not Tested 
The synthesized compounds exhibited moderate activity against fungal strains using Clotrimazole as standard (positive control). Mannich bases (5a) \& (5b) are effective than Schiff base (4). Against fungal strains, Mannich bases (5b) showed more potent activity than (5a). The Schiff base (4) is more effective against $S$. cerevisiae than $C$. albicans, whereas Mannich bases are more effective against $C$. albicans than $S$. cerevisiae. Compound $\mathbf{5 b}$ with a more basic and less bulky substituent at $N 1$ of triazole nucleus exhibited comparatively more potent antimicrobial activity.

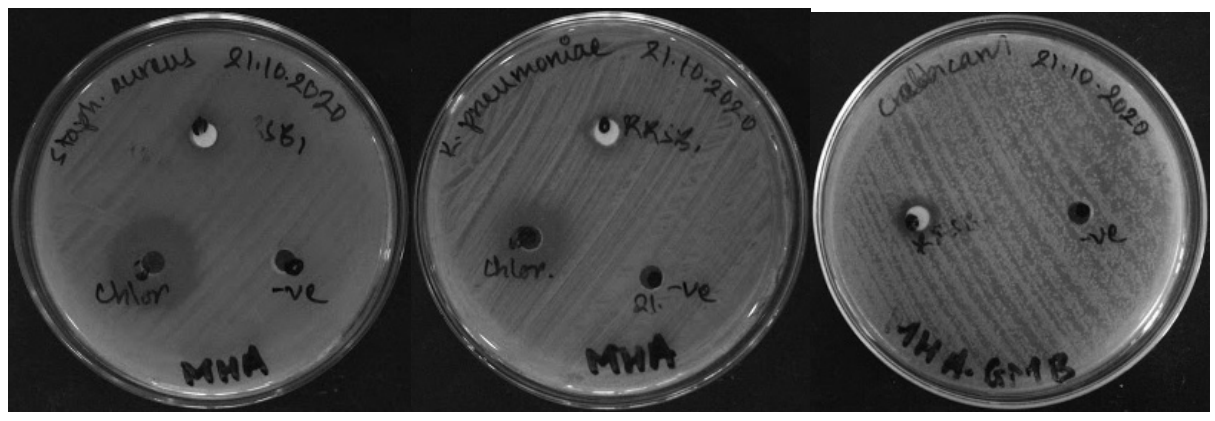

(a)

(b)

(c)

Fig 1. Antimicrobial activity of Schiff base against (a)Staphylococcus aureus (Gram +ve bacteria)

(b) Klebsiella pneumoniae (Gram -ve bacteria) and (c) Candida albicans (Fungi)

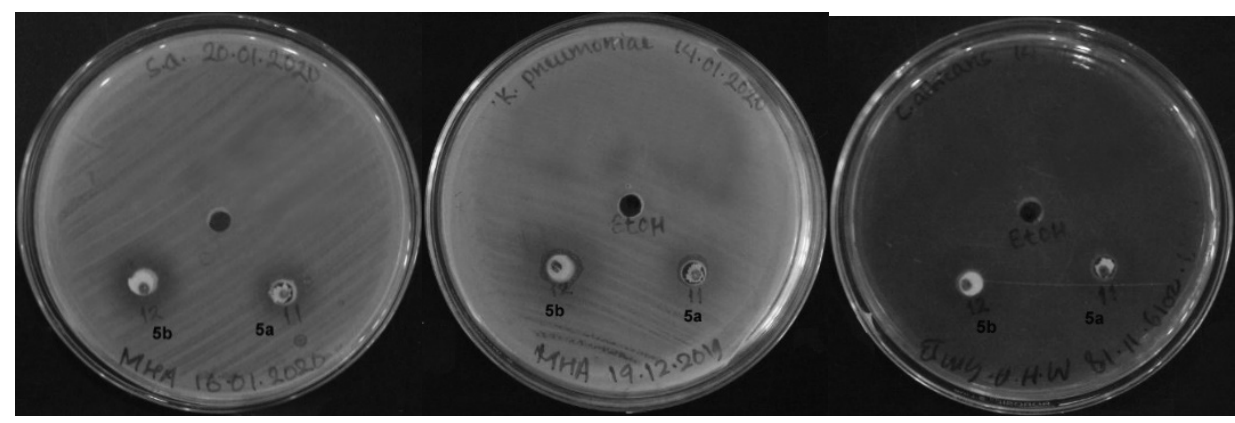

(a)

(b)

(c)

Fig 2. Antimicrobial activity of Mannich base against (a)Staphylococcus aureus (Gram +ve bacteria)

(b) Klebsiella pneumoniae (Gram-ve bacteria) and (c) Candida albicans (Fungi)

\section{Conclusions}

Schiff base 3-(2-hydroxyphenyl)-4-(4-methoxybenzylideneamino)-1H-1,2,4-triazole-5-thione (4); Mannich bases 2-(diphenylamino)methyl-3-(2-hydroxyphenyl)-4-(4-methoxybenzylideneamino)-1,2,4-triazole-5-thione

(5a) and 3-(2-hydroxyphenyl)-4-(4-methoxybenzylideneamino)-2-(piperazin-1-ylmethyl)-1,2,4-triazole-5-thione (5b) were prepared successfully in lab. The characterization of newly synthesized compounds was done by spectroscopic techniques (UV, FTIR, and NMR). The synthesized compounds showed moderate activities against bacterial strain and were found to be very effective against the fungal strains. The Mannich bases (5a \& $\mathbf{5 b}$ )are found to be much more effective than Schiff base (4) against bacterial strains as well as fungal strains. The difference in activities of $\mathbf{5 a}$ and $\mathbf{5 b}$ suggest that antimicrobial activities of Mannich bases are influenced by the bulkiness of the substituent and electron density at $N 1$ of triazole nucleus.

\section{Acknowledgements}

The authors would like to acknowledge the University Grants Commission of Government of Nepal for the support through Faculty Research Grant provided to PI Bhushan Shakya (FRG-2075/76-S\&T-3), SAIF, IIT Madras, Chennai, India for NMR spectra; Department of Plant Resource, Thapathali, Kathmandu, Nepal for the FT-IR spectra and antimicrobial screening; and Hari Bhakta Oli (Department of Chemistry, Amrit Campus) for the UV-visible data acquisition. 


\section{References}

1. C.G. Bonde, N.J. Gaikwad. Synthesis and preliminary evaluation of some pyrazine containing thiazolines and thiazolidinones as antimicrobial agents, Bioorganic \& Medicinal Chemistry. 2004, 12(9), 2151-2161. (DOI: 10.1016/j. bmc.2004.02.024).

2. M. Koca, S. Servi, C. Kirilmis, M. Ahmedzade, C. Kazaz, B. Ozbek, G. Otuk. Synthesis and antimicrobial activity of some novel derivatives of benzofuran: part 1. Synthesis and antimicrobial activity of (benzofuran-2-yl)(3-phenyl-3methylcyclobutyl) ketoxime derivatives, European Journal of Medicinal Chemistry, 2005, 40(12), 1351-1358. (DOI: 10.1016/j.ejmech.2005.07.004).

3. V.J. Ram, A.J. Vlietinck. Chemotherapeutical agents. VII. Synthesis and pesticidal activities of sulphides and sulphones derived from bis[4-aryl-1,2,4-triazoline-5-thione-3-yl]alkane and 5-phenyl-1,3,4-oxadiazole-2-thione, Journal of Heterocyclic Chemistry, 1988, 25(1), 253-256. (DOI: 10.1002/jhet.5570250141).

4. A. Kamal, M.A. Syed, S.M. Mohammed. Therapeutic potential of benzothaizole: A Patent Review (2010- 2104), Informative healthcare, 2015, 25(3): 335-349.

5. F. A. Muhlthau, T. Bretschnider, R. Fischer, M. Fublein, M. Heil, A. Hense, J. Kluth, A. Kohler,E-M. Franken, O. Malsam, A. Voerste, P. Jeschke, A. Becker, P. Losel, Y. Sato. Heterocyclic compounds as pesticides. United States Patent, US-0183709, (2011-07-15).

6. P. Gourdon, J.L. Andersen, K.L. Hein, M. Bublitz, B.P. Pedersen, X.Y. Liu, L. Yatime, M. Nyblom, T.T. Nielsen, C. Olesen J.V. Moller, P. Nissen, J.P. Morth,. HiLi De-systematic approach to membrane protein crystallization in lipid and detergent. Crystal Growth and Design. 2011, 11(6), 2098-2106. (DOI: 10.1021/cg101360d).

7. P. Yang, P. Martos, B. Barrett. $51^{\text {st }}$ North American Chemical Residue Workshop. Journal of Agricultural and Food Chemistry. 2015, 63(21), 5099-5099. (DOI: 10.1021/acs.jafc.5b00159).

8. Y. Andrei. Introduction: Small Heterocycles in Synthesis. Chemistry Reviews, 2014, 114(16), 7783-8360. (DOI. org/10.1021/cr500323m).

9. K. Fuji, S. Tamba, K. Shono, A. Sugie, A. Mori. Murahashi coupling polymerization: Nickel(II)-N-heterocyclic carbene complex-catalyzed polycondensation of organolithium species of (hetero)arenes, Journal of American Chemical Society, 2013, 135(33), 12208- 12211. (DOI: 10.1021/ja406374t).

10. J. Burschka, A. Dualeh, F. Kessler, E. Baranaoff, N. Cevey-Ha, C. Yi, M.K. Nazeeruddin, M. Gratzel. Tris(2-(1H-pyrazol1-yl)pyridine) cobalt(III) as p-type dopant for inorganic semiconductor and its application in highly efficient solid-state dye-sensitized solar cells, American Chemical Society, 2011, 133(45), 18042-18045. (DOI:10.1021/ja207367t).

11. Y. Hua, S. Chang, D. Huang, X. Zhou, X. Zhu, J. Zhao, T. Chen, W.Y. Wong, W.K. Wong. Significant improvement of dye-sensitized solar cell performing using simple phenothiazine-based dyes, Chemistry of Materials, 2013, 25(10), 2146-2135.

12. V. Thottempudi, F. Foroohar, D.A. Parrish, J.M. Shreeve. Tris(triazolo)benzene and its derivatives: High-density energetic materials. Angewandte Chemie, International Edition in English, 2012, 51(39), 9881-9885. (DOI: 10.1002/ anie.201205134).

13. K. El Akri, K. Bougrin, J. Balzarini, A. Faraj, R. Benhida. Efficient synthesis and in vitro cytostatic activity of 4-substituted triazolyl-nucleosides. Bioorganic \& Medicinal Chemistry Letters, 2007, 17(23), 6656-6659. (DOI: 10.1016/j.bmcl.2007.08.077).

14. M.S. Karthikeyan, B.S. Holla, N.S. Kumari. Synthesis and antimicrobial studies of novel dichlorofluorophenyl containing aminotriazolothiadiazines, European Journal of Medicinal Chemistry, 2008, 43(2), 309-314. (DOI: 10.1016/j. ejmech.2007.03.024).

15. M. Gokce, B. Cakir, K. Earl, M. Sahin. Synthesis and antimicrobial activity of [(2-oxabenzothiazolin-3-yl)-methyl]-4alkyl/aryl-1,2,4-triazoline-5-thiones. Archiv der Pharmazie, 2001, 334, 279-283. 
16. A. Varvarason, A. Tantili-Kakoulidou, T. Siatra- Papastasikoudi, E. Tiligada. Synthesis and biological evaluation of indole containing derivatives of thiosemicarbazide and their cyclic 1,2,4-triazole and 1,3,4-thiadiazole analogs, Arzneimittel Forschchung, 2000, 50, 48-54.

17. H. Chen, Z. Li, Y. Han. Synthesis and fungicidal activity against Rhizoctonia solani of 2-alkyl(alkylthio)-5-pyrazolyl1,3,4-oxadiazoles (thiadiazoles), Journal of Agricultural and Food Chemistry, 2000, 48(11), 5312-5315. (DOI: 10.1021/ jf991065s).

18. X.J. Zou, L. H. Lai, G.Y. Jin, Z.X. Zhang. Synthesis, fungicide activity and 3D-QSAR of 1,3,4-oxadiazoles and 1,3,4-thiadiazoles, Journal of Agricultural and Food Chemistry, 2002, 50(13), 3757-3760. (DOI: 10.1021/jf0201677).

19. K.P. Kapri, S.B. Singar, S. Khanal, B. Shakya. Synthesis of Schiff bases of 4-amino-5-(2-hydroxyphenyl)-4H-1,2,4triazole-3-thiol as potent antimicrobial agents, Amrit Research Journal, 2020, 1(1), 29-36. (DOI: 10.3126/arj.v1i1.32450).

20. R.S. Upadhayaya, G.M. Kulkarni, N.R. Vasireddy, J.K. Vandavasi, S.S. Dixit, V. Sharma, J. Chattopadhyaya. Design, synthesis and biological evaluation of novel triazole, urea and thiourea derivatives of quinolone against Mycobacterium tuberculosis. Bioorganic \& Medicinal Chemistry, 2009, 17(13), 4681-4692. (DOI: 10.1016/j.bmc.2009.04.069).

21. G.D. Diana, T.J. Nitz, J.P. Mallamo, A. Treasurywala. Antipicornavirus compounds: use of rational drug design and molecular modelling, Antiviral Chemistry and Chemotherapy, 1993, 4(1), 1-10. (DOI: 10.1177/095632029300400101).

22. M. Julino, M.F.G. Stevens. Antitumour polycyclic acridines. Part 5. Synthesis of 7H-pyrido[4,3,2-kl]acridines with exploitable functionality in the pyridine ring, Journal of the Chemical Society, Perkin Transactions, 1998, 1, 1677-1684. (DOI: 10.1039/A800575C).

23. R. Paprocka, M. Wiese, A. Eljaszewicz, A. Helmin-Basa, A. Gzell, B.M. Banachiewicz, J. Michalkiewicz. Synthesis and anti-inflammatory activity of new 1,2,4-triazole derivatives, Bioorganic \& Medicinal Chemistry Letters, 2015, 25(13), 2664-2667. (DOI: 10.1016/j.bmcl.2015.04.079).

24. I.K. Kucukguzel, S.G. Kucukguzel, S. Rollas, G. Otuk-Sanis, O. Ozdemir, I. Bayrak, T. Altug, J.P. Stables. Synthesis of some 3-(arylalkylthio)-4-alkyl/aryl-5-(4-aminophenyl)-4H-1,2,4-triazole derivatives and their anticonvulsant activity, Il Farmaco, 2004, 59(11), 893-901. (DOI: 10.1016/j.farmac.2004.07.005).

25. A. Passannanti, P. Diana, P. Barraja, F. Mingoia, A. Lauria, G. Cirrincione. Pyrrolo[2,3-d][1,2,3]triazoles as potential antineoplastic agents, Heterocycles, 1998, 48(6), 1229-1235. (DOI: 10.3987/COM-98-8130).

26. B.S. Holla, B. Veerendra, M.K. Shivananda, B. Poojary. Synthesis characterization and anticancer activity studies on some Mannich bases derived from 1,2,4-triazoles, European Journal of Medicinal Chemistry, 2003, 38(7-8), 759-767. (DOI: 10.1016/S0223-5234(03)00128-4).

27. S. Schenone, O. Bruno, A. Ranise, F. Bondavalli, W. Fillippelli, G. Falcone, L. Giordano, M.R. Vitelli. 3-Arylsulphonyl5-arylamino-1,3,4-thiadiazol-2(3H)ones as anti-inflammatory and analgesic agents, Bioorganic \& Medicinal Chemistry, 2001, 9(8), 2149-2153. (DOI: 10.1016/S0968-0896(01)00121-3).

28. K. Ilango, P. Valentina. Synthesis and Biological Activities of Novel 1,2,4-triazolo-[3,4-b]-1,3,4-thiadiazoles, Der Pharma Chemica, 2010, 2(2), 16-22.

29. J. Fischer, C.R. Ganellin. Analogue-based Drug Discovery, John Wiley \& Sons., 2006, pp. 531. ISBN 9783527607495.

30. V. Calderone, I. Giorgi, O. Livi, E. Martinotti, E. Mantuano, A. Martelli, A. Nardi. Benzoyl and/or benzyl substituted 1,2,3-triazoles as potassium channel activators. VIII, European Journal of Medicinal Chemistry, 2005, 40(6), 521-528. (DOI: 10.1016/j.ejmech.2005.01.010).

31. A. Brucato, A. Coppola, S. Gianguzza, P.M. Provenzano. Triazolam: Characteristics of its depressive action, Bollettino della Societa Italiano di Biologia Sperimentale, 1978, 54(11), 1051-1057.

32. R. Goldberg. Drugs across the spectrum. $6^{\text {th }}$ ed. Cengage Learning, Boston, Massachusetts, USA, 2009, pp. 195. ISBN 9781111782009 .

33. J. Haber. Present status and perspectives on antimycotics with systematic effects, Casopis Lekaru Ceskych, 2001, 140(19), 596-604. 
34. The Merck Index. Merck \& Company, Inc Whitehouse Station, $12^{\text {th }}$ Edition, 1996.

35. M. Shiroki, T. Tahara, K. Araki. Japanese Patent, 75100096, Chemical Abstract, 1975, 84, 59588k.

36. F.D. Povelitsa, A.G. Gural. Antibiotiki Moscow, 1973; 18: 71. Chem. Abstr., 78, 93044.

37. C.D. Blanton, W. Nobles. Use of 3-azabicyclo[3.2.2]nonane in the Mannich reaction I, Journal of Pharmaceutical Science, 1962, 51(9), 878-881. (DOI: 10.1002/jps.2600510914).

38. E.P. Jesudason, S.K. Sridhar, E.J.P. Malar, P. Shanmugapandiyan, M. Inayathullah, V. Arul, D. Selvaraj, R. Jayakumar. Synthesis, pharmacological screening, quantum chemical and in vitro permeability studies of N-Mannich base of benzimidazoles through bovine cornea, European Journal of Medicinal Chemistry, 2009, 44(5), 2307-2312. (DOI: 10.1016/j.ejmech.2008.03.043).

39. C. Perez, M. Pauli, P. Bazerque. An antibiotic assay by agar well diffusion method, Acta Biologiae et Medicinae Experimentalis, 1990, 15, 113-115.

40. K. Devkota, G. Pathak, B. Shakya. Synthesis and evaluation of Schiff base of 4-amino-5-(chlorine substituted phenyl)-4H1,2,4-triazole-3-thione as antimicrobial agents, Journal of Nepal Chemical Society, 2020, 41(1), 26-35. (DOI:10.3126/ jncs.v41il.30373).

41. O.D. Cretu, S.F. Barbuceanu, G. Saramet, C. Draghici. Synthesis and characterization of some 1,2,4-triazole-3(4H)thiones obtained from intramolecular cyclization of new 1-(4-(4-X-phenylsulfonyl)benzoyl)-4-(4-iodophenyl)-3thiosemicarbazides. Journal of Serbian Chemical Society, 2010, 75(11), 1463-1471. (DOI: 10.2298/JSC091221122C).

42. D. Sunil, A.M. Isloor, P. Shetty, B. Chandrakantha, K. Satymoorthy. Synthesis, characterization, and in vitro cytotoxic properties of some new Schiff and Mannich bases in Hep G2 cells, Medicinal Chemistry Research, 2011, 20(7), 10241032. (DOI: 10.1007/s00044-010-9433-z)

43. M. Hanif, Z.H. Chohan, Z.H. Synthesis, spectral characterization and biological studies of transition metal(II) complexes with triazole Schiff bases, Applied Organometallic Chemistry, 2013, 27(1), 36-44. (DOI: 10.1002/aoc.2936).

44. S. Baluja, S. Chanda, R. Chabhadiya, N. Kachhadia, R. Nair, A. Solanki. A facile synthesis and the antimicrobial activity of some 4-aryltriazoles, Journal of the Serbian Chemical Society, 2007, 72(6), 539-544. (DOI: 10.2298/JSC0706539B).

45. K. Zamani, K. Faghihi, T. Tofighi, M.R. Shariatzadeh. Synthesis and antimicrobial activity of some pyridyl and naphthyl substituted 1,2,4-Triazole and 1,3,4-thiadiazole derivatives, Turkish Journal of Chemistry, 2004, 28, 95-100.

46. R. M. Silverstein, F.C. Webster. Spectrometric identification of organic compounds, 6th ed., John Wiley, USA, 2002, 3, pp. 106.

47. B. Wang, Y. Shi, Y. Zhan, L. Zhang, Y. Zhang, L. Wang, X. Zhang, L. Yonghong, L. Zhengming, L. Baoju. Synthesis and biological activity of novel furan/thiophene and piperazine-containing (bis)1,2,4-triazole Mannich bases, Chinese Journal of Chemistry, 2015, 33(10), 1124-1134. (DOI: 10.1002/cjoc.201500436).

48. Y.M. Issa, H.B. Hassib, H.E. Abdelaal. ${ }^{1} \mathrm{H}$ NMR, ${ }^{13} \mathrm{C}$ NMR and mass spectral studies of some Schiff bases derived from 3-amino-1,2,4-triazole. Spectrochimica Acta Part A: Molecular and Biomolecular Spectroscopy, 2009, 74(4), 902-910. (DOI: 10.1016/j.saa.2009.08.042). 